\title{
EFFECT OF SOIL MANAGEMENT ON THEIR THERMAL PROPERTIES
}

\author{
Efecto del manejo del suelo sobre sus propiedades térmicas
}

\author{
Dorota Dec ${ }^{1}$, José Dörner ${ }^{1}$ and Rainer Horn ${ }^{2}$ \\ ${ }^{1}$ Instituto de Ingeniería Agraria y Suelos, Universidad Austral de Chile, Casilla 567, \\ Valdivia, Chile. Corresponding author:dorkadd@gmail.com \\ ${ }^{2}$ Institute for Plant Nutrition and Soil Science, Christian Albrechts University of Kiel, \\ Germany.
}

\begin{abstract}
In order to determine the effect of soil management on its thermal properties, undisturbed soil samples were taken from two tillage treatments (conventional and conservation treatment) at two depths $(0-30 \mathrm{~cm}$ and $30-60 \mathrm{~cm})$ of a Stagnic Luvisol (silt loam) before and after directly wheeling. The experimental field, located in Harste/Goettingen, Germany, was cultivated with sugar beet (Beta vulgaris). To calculate thermal properties of the soil, the volumetric water content (TDR needles) and temperature (pT 100 thermistors) during the simulation of the daily fluctuation of temperature were registered in laboratory and then the thermal conductivity, volumetric heat capacity and heat diffusivity were calculated following the damping depth method and the statistical-physical model. The results showed that different tillage systems as well as compaction influenced soil thermal properties. Conservational tillage treatment with more stable and better developed soil structure at a depth of $0-30 \mathrm{~cm}$ (which represents ploughing depth and decides differences between soil management) presented higher water content as the main factor deciding soil thermal properties. According to this, values of thermal conductivity and volumetric heat capacity under this treatment were greater than under conventional. Thermal diffusivity, however, was lower. From the latter we can conclude that under conservation tillage treatment the soil can store more heat, but at the same time and as a result of the lower thermal diffusivity, the atmospheric variations do not affect the soil thermal regime strongly.
\end{abstract}

Keywords: heat capacity, heat conductivity, thermal diffusivity, tillage system.

\section{RESUMEN}

Con el objetivo de determinar el efecto del manejo del suelo sobre sus propiedades térmicas, se recolectaron muestras no disturbadas de suelo desde dos tratamientos de cultivo (convencional y conservacionista) en dos profundidades (0-30 cm y 30-60 cm) de un Stagnic Luvisol (franco limoso) antes y después del tránsito de una cosechadora. El campo experimental, ubicado in Hartse/Goettingen, Alemania, fue cultivado con remolacha azucarera (Beta vulgaris). Para calcular las propiedades térmicas del suelo, se registró el contenido volumétrico de agua (TDRs) y la temperatura (thermistors pT100) durante la simulación de la fluctuación diaria de la temperatura en laboratorio. A partir de esa simulación, se calculó la conductividad térmica, la capacidad calórica y la difusión de calor de acuerdo al método "damping depth" y "statistical-physical model". Los resultados demuestran que tanto los diferentes tipos de manejo como también la compactación del suelo afectan sus propiedades térmicas. El manejo conservacionista presenta una estructura mas estable y mejor desarrollada entre $0-30 \mathrm{~cm}$ de profundidad (en donde se realizan las labores culturales y marca la diferencia entre sistemas de manejo de suelo) presenta un 
mayor contenido de agua, siendo este el factor que rige sobre las propiedades térmicas. De acuerdo a eso, la conductividad térmica y la capacidad calórica en ese tratamiento fueron mayores que la observada en el manejo convencional. La difusión térmica, sin embargo, fue mas baja. De esto se puede concluir que el suelo en un sistema conservacionista puede almacenar una mayor cantidad de calor, pero al mismo tiempo y como resultado de la menor difusión térmica, su régimen térmico no se ve tan alterado con las fluctuaciones atmosféricas.

Palabras claves: capacidad calórica, conductividad térmica, difusión térmica, sistema de labranza

\section{INTRODUCTION}

Soil temperature and, consequently their thermal properties are one of the most important factors governing the exchange of energy and mass between the soil and the atmosphere (Tyson et al., 2001). The influence of temperature on soil is noticeable already at the level of their formation, through their direct influence on the weathering of bedrock to produce mineral particles. Then, the temperature influences biological processes, like the uptake of water and nutrients by roots, germination, seedling emergence and plant growth as well as influences decomposition of organic matter by microbes rising with a temperature increase (Bachmann et al., 1997; Hillel 1998; Zawadzki et al., 1999). This in turn implies an increase in oxygen consumption and the development of anaerobic sites in the soil (Maag and Finn, 1999), affecting the frequency and magnitude of soil chemical reactions, and the rate of plant growth (Zawadzki et al., 1999). Agricultural soils should have the ability to support plant growth by providing nutrients, gas, water, heat through a rootable pore system. Soil structure has a major influence on these properties, therefore, they are exposed to continuous changes, whether due to wetting and drying cycles (internal forces inducing structural changes) or human activities (external forces, e.g. soil compaction). The latter often causes severe changes in soil structure which may have detrimental impacts on soil functions, e.g. soil disturbance due to tillage that decreases the amount of organic matter, affect the aggregate stability and alters the heat flux due to changes of the surface roughness. This in turn changes the area of the soil surface which is in contact with the atmosphere and, consequently soil thermal properties decreases. On the other hand, the soil compaction induces an increase in the number of contacts points between soil particles, and consequently, the thermal conductivity also increases (Hopmans and Dane, 1986; Nidal et al., 2000). In order to describe the effect of tillage management practises on soil thermal properties, the objectives of this work were: (1) determine the soil thermal properties with method of damping depth and a statistical-physical model compiled by Usowicz (1991) under conventional and conservation tillage treatment and (2) evaluate the effect of soil compaction on soil thermal properties.

\section{MATERIAL AND METHODS}

\section{Soil material and management}

The investigation was conducted on arable soils in a slightly undulating area in Northern Germany. The used soil material was Stagnic Luvisol (FAO, 1998) derived from loess represented by two tillage treatments: Conservation (Mulch) and Conventional (Plough). Mulch defines the treatment when the soil is loosened with a field cultivator to a depth of $8-10 \mathrm{~cm}$, while Plough means ploughing and complete converting down to $30 \mathrm{~cm}$ depth. Before 1992 the whole field 
Tabla 1: Propiedades físicas de los suelos estudiados

Table 1: Physical properties of the studied soils

\begin{tabular}{|c|c|c|c|c|c|c|}
\hline Site & $\begin{array}{c}\text { Sand } \\
{[\%]}\end{array}$ & $\begin{array}{c}\text { Silt } \\
{[\%]}\end{array}$ & $\begin{array}{c}\text { Clay } \\
{[\%]}\end{array}$ & $\begin{array}{c}\mathrm{d}_{\mathrm{B}} \\
{\left[\mathrm{g} \mathrm{cm}^{-3}\right]}\end{array}$ & $\begin{array}{c}\text { TP } \\
{[\%]}\end{array}$ & $\begin{array}{c}\text { Corg } \\
{\left[\mathrm{mg} \mathrm{g}^{-1}\right]}\end{array}$ \\
\hline $\mathrm{P}$ & 3 & 80 & 17 & $1.53 \mathrm{a}$ & 42 & 1.4 \\
\hline $\mathrm{M}$ & 3 & 80 & 17 & $1.47 \mathrm{a}$ & 44 & 1.4 \\
\hline
\end{tabular}

P - Plough; M- Mulch; $\mathrm{d}_{\mathrm{B}}$-bulk density $\left[\mathrm{g} \mathrm{cm}^{-5}\right.$; TP -total porosity [\%]; Corg -content of organic carbon $\left[\mathrm{mg} \mathrm{g}^{-1}\right]$

was uniformly ploughed to $30 \mathrm{~cm}$ depth. At the sampling time the soil was cultivated with sugar beet (Beta vulgaris). Some physical properties of the studied soils are shown in Table 1.

\section{Collection of undisturbed soil samples}

The soil sampling took place in November 2003, directly after sugar beet harvesting (with a "Holmer Terra Dos"; weight of the half loaded machine $35-40 \mathrm{Mg}$ ). Undisturbed soil samples were taken at a depth of 0-30 and $30-60 \mathrm{~cm}$ before and after compaction (using plastic cylinders; $\mathrm{h}=30 \mathrm{~cm}, \varnothing=19 \mathrm{~cm}$ ). For description of the tillage treatments the following notation was used: $\mathrm{Mb} / \mathrm{Ma}$ for Mulch before/after wheeling; $\mathrm{Pb} / \mathrm{Pa}$ for Plough before/after wheeling, respectively. After sampling the soil samples were put into plastic bags to avoid evaporation.

\section{Measurements}

In order to determine the effect of tillage treatment and soil compaction on thermal properties (thermal conductivity- $\lambda$, heat capacity- $\mathrm{Cv}$, thermal diffusivity- D) the simulation of daily temperature oscillation under laboratory conditions was carried out on the soil samples.

\section{Simulation of daily temperature oscillation}

First the cylinders were saturated and then wrapped with isolations (cotton wool and styropour) to minimize the influence of external factors, and then sensors for measuring water content (TDR needle from
Fa. Easy Test, Ltd., Poland) and temperature (pT 100 thermistors) were put into the soil at defined depths (2.5- 6.5- 10.5 and 14.5 $\mathrm{cm})$. A heating lamp, fixed above the samples, was used to heat the soil from the surface. The measurement consisted of two phases: warming phase - the intensity of the applied heat increases (seven steps) and the cooling phase - heat intensity decreases (next seven steps). Each step takes 30 minutes, and the whole monitoring about 25 hours (after warming and cooling phase the sample was leaved to obtain uniform temperature). The intensity of heat at the soil surface from the heating lamp was manually controlled (the heating lamp was shifted up and down).

\section{Calculations}

Estimation of the thermal diffusivity by statistical -physical model compiled by Usowicz

For determination of soil thermal properties the statistical-physical model compiled by Usowicz (1991, 1992 and 2002) was used. This model is based on terms of the heat resistance (Ohm's and Fourier's laws), laws of Kirchhoff, and the polynomial distribution. In this model the volumetric unit of the soil consists of solid particles, water and air and is treated as a system made up of the elementary geometric figures (in this case spheres) which form overlapping layers. Connections between layers of the spheres and the layer between 
neighbouring spheres are represented by the serial and parallel connections of thermal resistors, respectively. The average value of the thermal conductivity is estimated by comparison of resultant resistance of the system, with consideration of all possible configurations of particle connections together with a mean thermal resistance of a given soil volume unit. Precise description of this method is presented in Usowicz (1992, 2000). The thermal capacity and diffusivity were calculated with empirical formulas described in Hillel (1998).

\section{Estimation of the thermal diffusivity by the Damping Depth method}

Thermal diffusivity was also calculated by the damping depth method used before by e.g. Hanks and Ashcroft (1980), Usowicz (2001) and Chacko and Renuka (2002). The main assumption of this method is the harmonic development of the temperature changes during daily or yearly cycles. If this condition is fulfilled the damping depth (d) (depth at which the amplitude decreases to the fraction of $1 / \mathrm{e}$ of the amplitude on the soil surface; $\mathrm{e}=2.718$ is the base of the natural logarithms) can be calculated from the phase shift (Figure 1a) and the amplitude ratio (Figure 1b) of the temperature wave which can be presented as a sinusoidal function (Chacko and Renuka, 2002). Temperature measurements in at least two depths $\mathrm{z}_{1}$ and $\mathrm{z}_{2}$ (Wierenga et al., 1969; Elimoel et al., 2004; Peth, 2004) are needed. From their graphic introduction the damping depth $[\mathrm{cm}]$ can be read directly from the slope of the line as describe the following equation 1 :

$$
d_{\text {amplitude }}=\frac{\left(z_{1}-z_{2}\right)}{\ln \left|A_{\text {mplz1 }}\right|-\ln \left|A_{m p l z 2}\right|}=\frac{\left(z_{1}-z_{2}\right)}{\ln \left|\frac{A_{\text {mplz1 }} \mid}{A_{\text {mplz2 }} \mid}\right|}
$$

where $A_{\text {mplz1 } 1}$ and $A_{\text {mplzz }}$ means amplitude of the temperature wave at depths $\mathrm{z}_{1}$ and $\mathrm{z}_{2}$ $\left[{ }^{\circ} \mathrm{C}\right]$

The harmonic development of the daily changed temperature profiles occurs by some short-time temperature variations and generally it is assumed that the daily average amplitude is constant with time. Under in situ conditions, however, this value is not constant and therefore in the equation 1 this value is taken as an annual average of the daily amplitude (Elimoel et al., 2004).

If the values of the damping depths estimated from the phase shift and amplitude ratio method are similar, the thermal diffusivity $\left[\mathrm{m}^{2} / \mathrm{s} * 10^{-7}\right]$ can be calculated from the following equation 2 :

$$
D=\left(\frac{\pi}{P}\right) d^{2}
$$

Figura 1: Introducción gráfica del cálculo de la profundidad de atenuación de acuerdo al a) desfase de tiempo y b) relación de amplitud

Figure 1: Graphical introduction of the damping depth calculation from the a) time shift and b) amplitude ratio

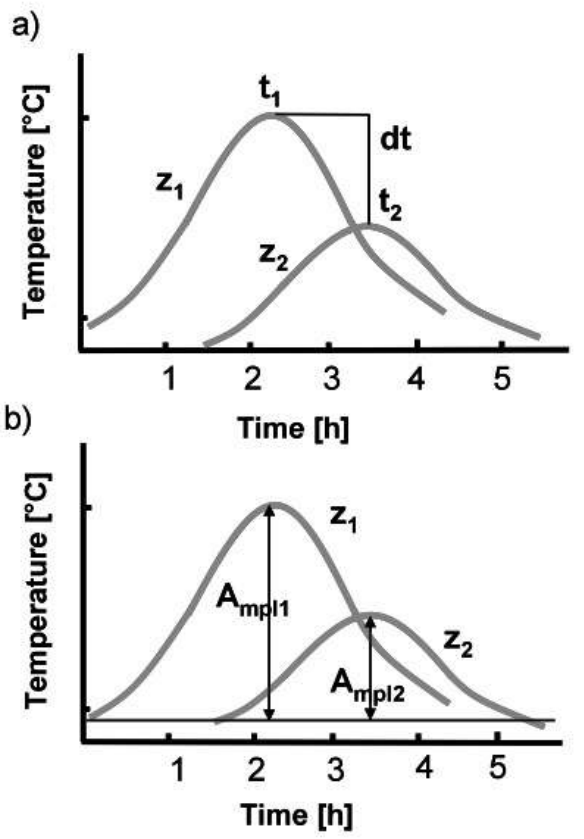


Where: $d$ is the average value estimated from amplitude and phase shift damping depth.

This method can be applied if the days are sunny and clear (Wierenga et al., 1982). If the changes in soil water content with depth are considerable, or when the temperature wave shows no periodic behaviour, this method can not be used (Wierenga et al., 1969; Chacko and Renuka, 2002). If the values of the damping depths are very different the application of equation 2 is not allowed.

\section{Statistical analysis}

Statistical analysis of bulk density $(n=6)$, thermal conductivity $(n=4)$ and heat capacity $(n=4)$ for two investigated treatment and tillage practices (unwheeled, wheeled plots) were performed by analysis of variance ( $\mathrm{p} \leq 0.05)$. The differences of means were assessed by the Tukey-Test ( $\mathrm{p} \leq 0.05)$.

\section{RESULTS}

\section{Effect of tillage treatment on no-wheeling plots}

Investigated tillage treatments before wheeling indicated some differences between plots and especially between sample depths. In Mulch greater minimum and maximum values of $\theta, \lambda$ and $C v$ were observed in the topsoil, while in Plough the situation was inverse (Table 2). Thermal diffusivity independent on tillage treatment reaches greater values for samples taken from the deeper soil horizon.

Variations (higher increase/decrease) of calculated $(\lambda, \mathrm{Cv}, \mathrm{D})$ properties as well as intensity of evaporation and maximal temperatures were greater in samples taken from depth of $0-30 \mathrm{~cm}$ (independent of the treatment).

The results obtained show that the differences between the sampled depths were observed not only for single treatments but also between them. Trends indicate that the presented properties (except T and D) for Mulch are greater in the topsoil, while, for Plough (except T) they were greater in samples collected from deeper depths (see also Table 3).

If only treatments are considered, the conservational system has a higher $\theta$ value at a given matric potential (Table 2) and, corresponding, $\lambda$ and $\mathrm{Cv}$ reach higher values (statistically not significant as shows Table $3)$. The conventional system indicated greater $\mathrm{T}$ and $\mathrm{D}$.

\section{Effect of tillage treatment on wheeling plots}

Plots after wheeling considered as single treatments show similar trends with the unwheeled ones (Table 3 and 4). In Mulch the investigated properties (except D) are greater in samples taken from the topsoil. In Plough the similar behavior is show for $\theta$ and $\mathrm{Cv}$, whereas $\lambda$ and $\mathrm{D}$ were higher in the samples taken from $30-60 \mathrm{~cm}$ depth. The maximal temperature was higher in $\mathrm{P}$ and the difference between the min and the max values of the investigated properties was greater in the samples collected from $0-30 \mathrm{~cm}$ (for both treatments).

If only treatments are considered it is visible that $\lambda$ and $\mathrm{Cv}$ are greater in conservation treatment (M) after wheeling (Table 3). These differences are statistically significant in the $0-30 \mathrm{~cm}$ layer. The influence of soil compaction on the investigated soil properties summarized in Table 2 and Table 4 show that for depth of $0-30 \mathrm{~cm}$, which is the most affected by management practices the measured $(T, \theta)$ as well as calculated $(\lambda, \mathrm{Cv}, \mathrm{D})$ properties were greater in samples after wheeling. The same situation was observed for majority of investigated parameters for samples taken from 30-60 $\mathrm{cm}$.

\section{Thermal diffusivity calculated with the damping depth method}

The accuracy of this method to determine D was assessed by depicting the relationship between the phase shift and the amplitude 
Tabla 2: Valores máximos y mínimos de las propiedades medidas ( $\mathrm{T}$ and $\theta$ ) y calculados $(\lambda, \mathrm{Cv}, \mathrm{D})$ en muestras recolectadas en sectores no transitados del manejo conservacionista (M) y convencional (P) a las profundidades de $0-30 \mathrm{~cm}$ y $30-60 \mathrm{~cm}$

Table 2: The maximum and minimum values of measured (T and $\theta$ ) and calculated $(\lambda$, $\mathrm{Cv}, \mathrm{D})$ properties for unwheeled samples taken from Mulch and Plough at depths of $0-30 \mathrm{~cm}$ and $30-60 \mathrm{~cm}$

\begin{tabular}{|c|c|c|c|c|}
\hline Property & \multicolumn{2}{|c|}{ Mulch } & \multicolumn{2}{c|}{ Plough } \\
\hline Depth $[\mathrm{cm}]$ & $0-30$ & $30-60$ & $0-30$ & $30-60$ \\
\hline $\mathrm{T}\left[{ }^{\circ} \mathrm{C}\right]$ & $19-32$ & $19-30$ & $21-33$ & $21-30$ \\
$\theta[\mathrm{vol} \%]$ & $40-28$ & $35-28$ & $33-26$ & $39-23$ \\
\hline$\lambda[\mathrm{W} / \mathrm{mK}]$ & $1.04-0.96$ & $1.03-0.95$ & $1.00-0.93$ & $1.065-0.95$ \\
\hline $\mathrm{Cv}\left[\mathrm{J} / \mathrm{m}^{3} \mathrm{~K}^{*} 10^{6}\right]$ & $2.85-2.38$ & $2.6-2.30$ & $2.6-2.25$ & $2.85-2.15$ \\
\hline $\mathrm{D}\left[\mathrm{m}^{2} / \mathrm{s}^{*} 10^{-7}\right]$ & $3.65-4.10$ & $3,92-4,18$ & $3.9-4.20$ & $3.78-4.4$ \\
\hline
\end{tabular}

Tabla 3: Conductividad térmica $(\lambda)$ y capacidad calórica volumétrica $(\mathrm{Cv})$ en las parcelas con Mulch (M) y Arado (P), antes (b) y después (a) del tránsito a 0-30cm profundidad (letras mayúsculas significan diferencia entre las parcelas a y b, y las letras minúsculas diferencias entre las tratamientos con nivel de significancia de $\mathrm{p}<0,05$ )

Table 3: Thermal conductivity $(\lambda)$ and volumetric heat capacity $(\mathrm{Cv})$ in Mulch $(\mathrm{M})$ and Plough (P), plots before (b) and after (a) wheeling at 0-30 cm depth (the cardinal letters mean the difference between $b$ and a plots, and small letters differences between treatments by significant level of $\mathrm{p}<0,05$ )

\begin{tabular}{|c|c|c|c|c|}
\hline Property & \multicolumn{2}{|c|}{$\lambda[\mathrm{W} / \mathrm{mK}]$} & \multicolumn{2}{c|}{$\mathrm{Cv}\left[\mathrm{J} / \mathrm{m}^{3} \mathrm{~K}\right]$} \\
\hline Plot & unwheeling & wheeling & unwheeling & Wheeling \\
\hline Mulch & $1.001 \mathrm{Ba}$ & $1.041 \mathrm{Aa}$ & $2.59 * 10^{6} \mathrm{Ba}$ & $2.64 * 10^{6} \mathrm{Aa}$ \\
\hline Plough & $1.000 \mathrm{Ba}$ & $1.014 \mathrm{Ab}$ & $2.59 * 10^{6} \mathrm{Aa}$ & $2.60^{*} 10^{6} \mathrm{Ab}$ \\
\hline
\end{tabular}

The cardinal letters mean the difference between unwheeling and wheeling plots, and small letters differences between treatments by significant level of $p<0,05$ 
Tabla 4: Valores máximos y mínimos de las propiedades medidas ( $\mathrm{T}$ y $\theta$ ) y calculadas $(\lambda, \mathrm{Cv}, \mathrm{D})$ en muestras colectadas en sectores transitados del manejo conservacionista $(\mathrm{M})$ y convencional $(\mathrm{P})$ a las profundidades de $0-30 \mathrm{~cm}$ y $30-60 \mathrm{~cm}$

Table 4: The maximum and minimum values of measured (T and $\theta$ ) and calculated $(\lambda$, $\mathrm{Cv}, \mathrm{D})$ properties for wheeled samples taken from Mulch and Plough and depths of $0-30 \mathrm{~cm}$ and $30-60 \mathrm{~cm}$

\begin{tabular}{|c|c|c|c|c|}
\hline Property & \multicolumn{2}{|c|}{ Mulch } & \multicolumn{2}{c|}{ Plough } \\
\hline Depth [cm] & $0-30$ & $30-60$ & $0-30$ & $30-60$ \\
\hline $\mathrm{T}\left[{ }^{\circ} \mathrm{C}\right]$ & $22-34$ & $22-34$ & $20-35$ & $20-34$ \\
$\theta[\mathrm{vol} \%]$ & $42.5-28$ & $35-25$ & $40-25$ & $37.5-18$ \\
\hline$\lambda[\mathrm{W} / \mathrm{mK}]$ & $1.075-0.96$ & $1.025-0.98$ & $1.05-0.97$ & $1.075-0.91$ \\
\hline $\mathrm{Cv}\left[\mathrm{J} / \mathrm{m}^{3} \mathrm{~K}^{*} 10^{6}\right]$ & $2.9-2.30$ & $2.65-2.20$ & $2.9-2.22$ & $2.8-2.00$ \\
\hline $\mathrm{D}\left[\mathrm{m}^{2} / \mathrm{s}^{*} 10^{-7}\right]$ & $3.6-4.20$ & $3.85-4.40$ & $3.65-4.20$ & $3.85-4.60$ \\
\hline
\end{tabular}

ratio damping depths (Figure 2). Both tillage treatments and depths show a good fit with the $1: 1$ line. Values of damping depths calculated for samples taken from $0-30 \mathrm{~cm}$ are more concentrated in the middle part of the dashed line, while for $30-60 \mathrm{~cm}$ the data are more spread along the cross line. Values of damping depth are higher in samples taken from $30-60 \mathrm{~cm}$ and plots before wheeling in turn, wheeled plots have higher values of dmin and lower dmax (for samples before wheeling from depth $0-30 \mathrm{~cm}$ $\mathrm{d}=5-20 \mathrm{~cm}$ and from $30-60 \mathrm{~cm} \mathrm{~d}=7-23 \mathrm{~cm}$; samples after wheeling show $7-17 \mathrm{~cm}$ and $9-22 \mathrm{~cm}$ respectively). Values are related to the phase shift damping depths.

The temperature amplitude used for calculations of $\mathrm{D}$ with this method reaches greater values for Mulch and decrease with soil depth (M: T=14 and $11^{\circ} \mathrm{C} ; \mathrm{P}: \mathrm{T}=12$ and $9^{\circ} \mathrm{C}$ for $0-30$ and $30-60 \mathrm{~cm}$ respectively).

Thermal diffusivity for all depths and treatments shows a very weak decreasing tendency (in fact not significant $\mathrm{P}>0.1$ ) with increasing water content (Figure 3a).
Their range for soil samples collected from the topsoil is greater for Plough, considering that both investigated treatments (also depths) present similar water content.

Samples taken from deeper horizons (Figure 3b) do not differ between the investigated treatments, however, if we compare the results with those for $0-30 \mathrm{~cm}$ $\left(\mathrm{D}=0.11 .7 * 10^{6} \mathrm{~m}^{2} / \mathrm{s}\right), \mathrm{D}$ (especially for $\left.\mathrm{M}\right)$, reaches higher values and the range is $0.22 .9 * 10^{-6} \mathrm{~m}^{2} / \mathrm{s}$.

In the wheeled plots the dependency between depth and treatment shows the same trend as those in the plots before wheeling. In samples taken from $30-60 \mathrm{~cm}$ depth (Figure 4b) D reaches higher values $\left(0.01-2.4 * 10^{-6} \mathrm{~m}^{2} / \mathrm{s}\right)$ than those from $0-30 \mathrm{~cm}$ $\left(0.03-1.2 * 10^{-6} \mathrm{~m}^{2} / \mathrm{s}\right.$ for $M$ and $0.04-2.1 * 10^{-6} \mathrm{~m}^{2} / \mathrm{s}$ for $\mathrm{P}$ (Figure $4 \mathrm{a}$ ), where Plough reaches higher values than Mulch. D shows a very weak decrease with increasing $\theta$ (Figure $4 \mathrm{a}, \mathrm{b}$ ). No important differences were noticed between plots before and after wheeling. 

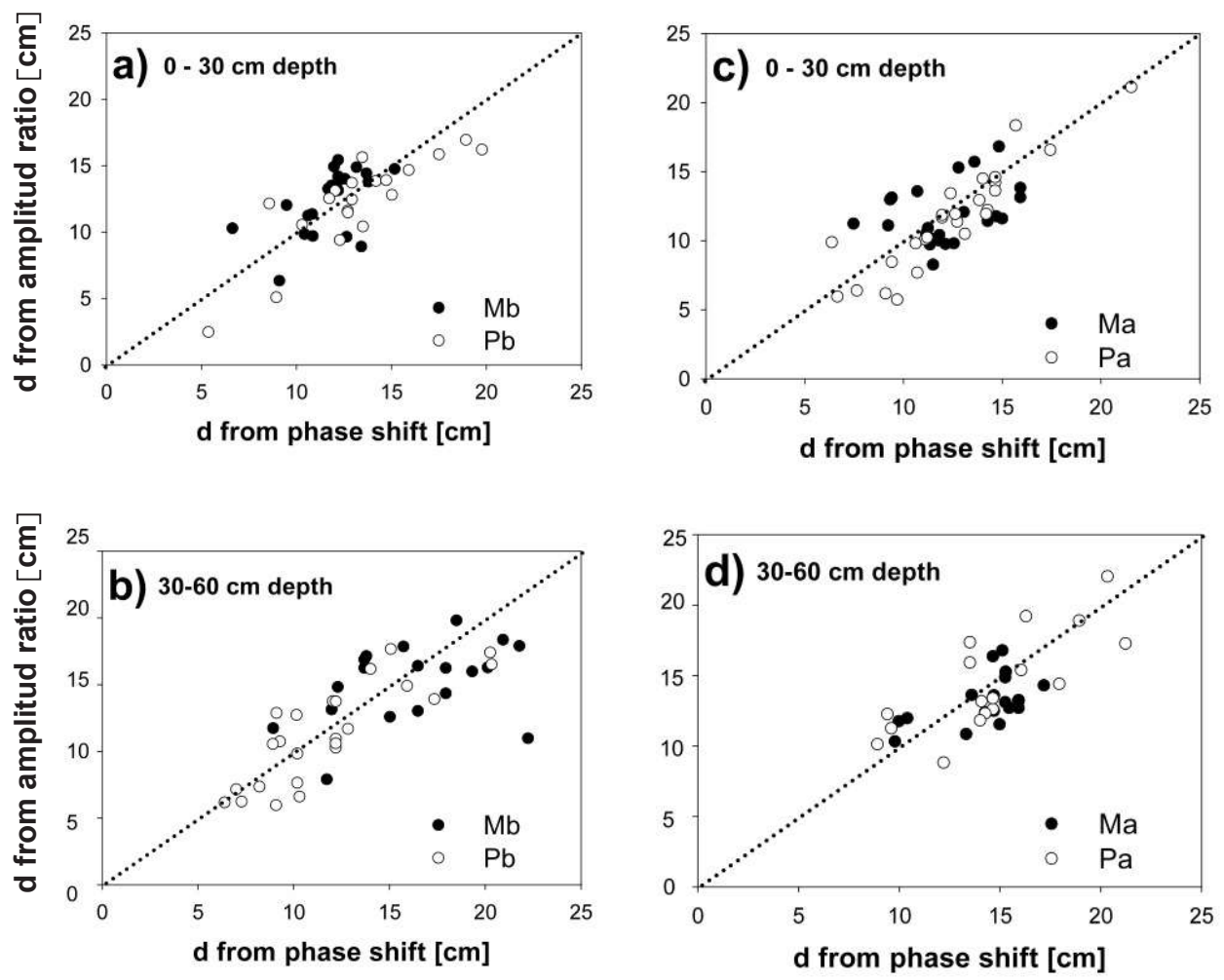

Figura 2: Relación entre profundidades de atenuación (d) calculadas a partir del desfase de tiempo y la relación de amplitud para las parcelas: a) no transitados $(\mathrm{Mb}, \mathrm{Pb}), \mathrm{c})$ transitados (Ma, Pa) de 0-30cm, y b) no transitados, d) transitados de $30-60 \mathrm{~cm}$

Figure 2: Relationship between damping depths (d) calculated from the phase shift and the amplitude ratio for: a) unwheeled $(\mathrm{Mb}, \mathrm{Pb}), \mathrm{c})$ wheeled $(\mathrm{Ma}, \mathrm{Pa})$ plots from $0-30 \mathrm{~cm}$, and b) un wheeled, d) wheeled plots from $30-60 \mathrm{~cm}$ 
34 Soil management and thermal properties, Dec et al.
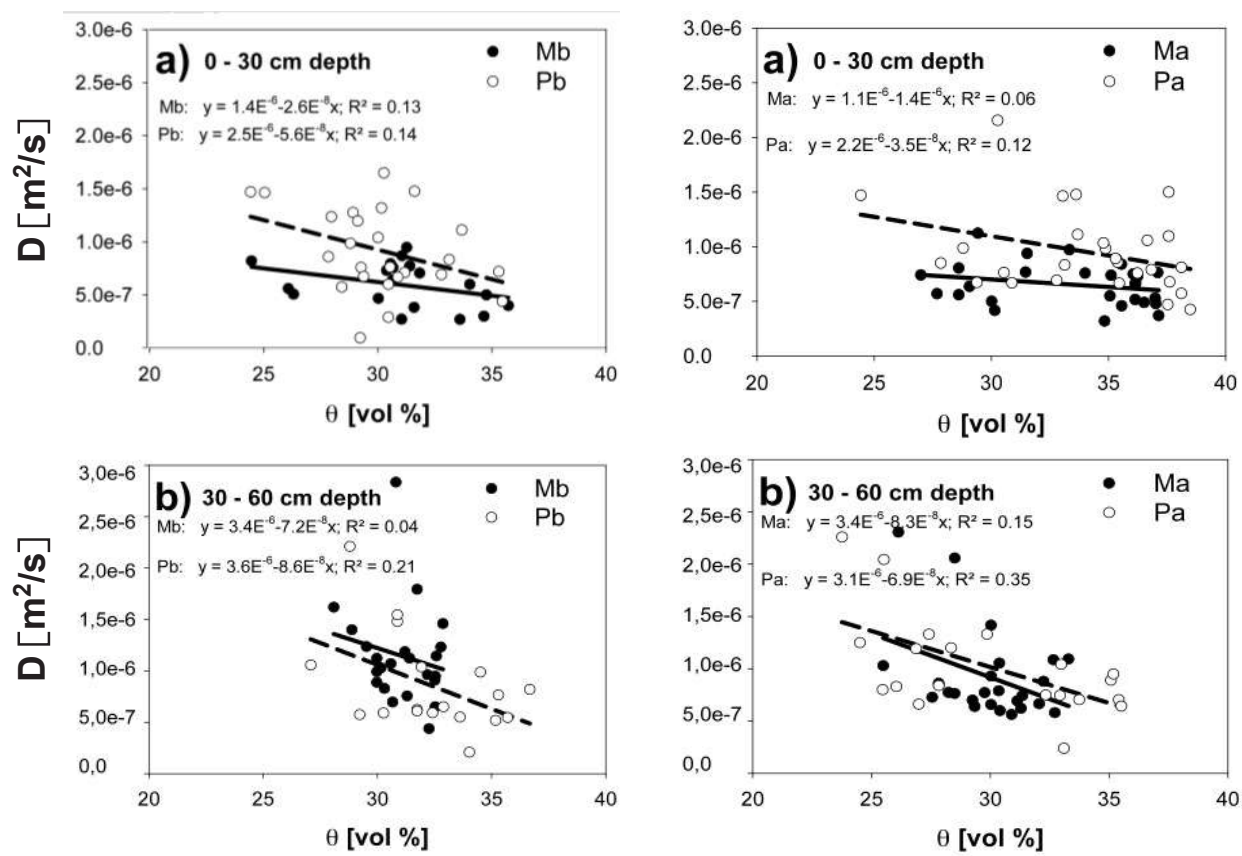

Figura 3: Difusión térmica calculada con el método de profundidad de atenuación para las muestras colectadas de $\mathrm{Mb}, \mathrm{Pb}$ y profundidades de: a) $0-30 \mathrm{~cm}$, b) $30-60 \mathrm{~cm}$

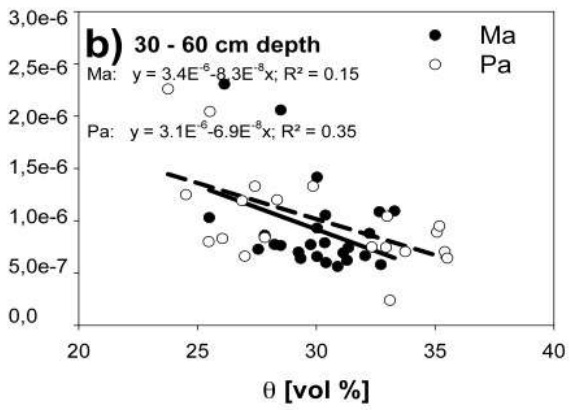

Figura 4: Difusión térmica calculada con el método de la profundidad de atenuación para las muestras recolectadas de $\mathrm{Ma}, \mathrm{Pa}$ a una profundidad de a) $0-30 \mathrm{~cm}$, b) $30-60 \mathrm{~cm}$

Figure 3: Thermal diffusivity calculated with damping depth method for samples taken from $\mathrm{Mb}, \mathrm{Pb}$ and depth of a) $0-30 \mathrm{~cm}$, b) $30-60 \mathrm{~cm}$

Figure 4: Thermal diffusivity calculated with damping depth method for samples taken from Ma, Pa and depth of a) $0-30 \mathrm{~cm}$, b) $30-60 \mathrm{~cm}$ 
The thermal diffusivity values calculated with the damping depth method (Figure 3, Figure 4) are smaller than those calculated with physical-statistical model, if the treatments before and after compaction are compared (Table 1, Table 3). However, calculations from both methods show greater values of D for samples taken from $30-60 \mathrm{~cm}$ depth.

\section{DISCUSSION}

\section{Effect of soil management on soil thermal properties calculated with damping method and statistical-physical model compiled by Usowicz}

Different soil management systems (e.g.: conventional, conservation, zero tillage or ecological farming, presence or lack of crop residue on the soil surface), affect their physical, hydraulic and, consequently, thermal properties. Crop residue has a major impact on soil thermal conductivity and heat capacity (Walczak and Usowicz, 1994) regarding their ability to reflect soil radiation, reduce evaporation and also to affect the net heat exchange (Hanks et al., 1971; Hay et al., 1978), the temperature gradient and the heat transfer. Also the different structure formation affected by tillage management alters the soil temperature and the thermal properties of soils. In our investigations samples taken from shallower depth (nominated difference between Plough and Mulch) show lower soil temperature under conservation tillage treatment (with higher water content) (Table 2 and 3). These findings are in agreement with those of Radke (1982), who investigated relations between soil water content and temperature, and observed lower temperature by higher soil moisture. He said that the soil warming under wet conditions is impeded due to greater soil heat capacity and more energy being used for water evaporation than warming the soil. Also Burrows and Larson (1962) and Kovar et al., (1992) reported lower soil temperature under no-tillage treatment due to uneven i.e.: interrupted physical conditions than in the ploughed layer and at the soil surface compared to conventional tillage.

Thermal conductivity and volumetric heat capacity are also affected by the tillage practices (Allmaras et al., 1977; AbuHamdech and Redder, 2000; Tyson et al., 2001) because of the tillage-induced soil compaction including wheeling, which increases the bulk density and the penetration resistance but creates a platy structure, which affects the water movement in the first centimeters of soil. Through loosening of soil by tillage the stability of aggregate is destroyed and also the heat flux through a changed surface roughness is altered (Potter et al., 1985). This, in turn changes the area of the soil surface which is in contact with the atmosphere and, consequently, decreases heat conductivity and thermal diffusivity (Johnson and Lowery, 1985; Noborio and McInnes, 1993; Arshad and Azooz, 1996; Nidal et al., 2000). These ascertainments find reflection in our investigations. In unwheeled as well as wheeled samples taken from depth of 0-30 cm the values of water content, heat conductivity and heat capacity were higher under conservational treatment (Table 2 and 4). Only thermal diffusivity was lower (Table 2 and 4; Figure 3a, 4a), however, this behavior can be explained with relations between this value and magnitude of soil water content. It is known that $\mathrm{D}$ depends on $\lambda$ and $\mathrm{C}_{\mathrm{V}}$ which increase with increasing water content. When a dry soil will be saturated the thermal conductivity increases more intensely than does the heat capacity. In moist soils the heat capacity increases linear with increasing water content, while a further increase of the water content results in a reduced increase of thermal conductivity. Thus, the thermal diffusivity after reaching some maximum value (volumetric water content between 8-20vol \%) (Arshad and Azooz, 1996) starts to decrease slowly (Potter et al., 1985) with continuously increasing water content (Bachmann et al., 1997; Hillel, 1998; Nofziger and Wu, 2002; Usowicz, 
2002, 2005). This smooth decrease is presented in Figures 3 and 4. Reduction of heat capacity in the tilled zone as a consequence of soil disturbance due tillage was also detected by Licht and Al-Kaisi (2005). They explained this with a phenomenon of shifting or changing of the air into soil particles volume which creates additional air pockets and is responsible for this reduction.

The contact area between soil particles or aggregates affected by tillage-induced homogenization of the soil also changes their thermal properties. Because soils shrink and swell, their thermal properties change temporarily especially immediately after soil tillage due to structure reformation. The intensity of these changes depends on the characteristics of the soil management, soil material, and climate conditions.

Since soil structure is more stable under conservation tillage, leading to enhanced particle contacts, thermal conductivity in the presented study is slightly greater under this treatment than under the conventional one. Thermal conductivity values reported here range between 1,05 and $0.95 \mathrm{~W} / \mathrm{mK}$ for Mulch unwheeled and between 1,0$0.93 \mathrm{~W} / \mathrm{mK}$ for Plough unwheeled. These data are higher than those presented by other authors like e.g.: Nidal et al., (2000) who determined $0.78-0.45 \mathrm{~W} / \mathrm{mK}$ and 0.72 $0.33 \mathrm{~W} / \mathrm{mK}$ for no-tillage, and ploughed plots, respectively (wheeled plots show the same dependencies). These differences, however, are caused by the higher water content in this study, which, as reported by Hopmans and Dane (1986), Azooz and Arshad (1995), de Vries (1996) and Hillel (1998), is the most important factor affecting this property. The heat conductivity decreases with the tillage intensity, which was detected also in the presented dataset for samples taken from the topsoil before and after compaction for both tillage treatments. These results agree with those of Nidal et al., (2000) who investigated clay loam and loam soil and estimated the highest heat conductivity for no-tillage and the smallest for rotary tillage.
The estimated values of heat capacity in the present analysis show the same dependencies between treatments as for heat conductivity. Under unwheeled conservation tillage treatment $\mathrm{Cv}$ ranged between $2.85-2.38 * 10^{6} \mathrm{~J} / \mathrm{m}^{2} \mathrm{~K}$ and under unwheeled conventional between $2.6-2.25^{*} 10^{6} \mathrm{~J} / \mathrm{m}^{2} \mathrm{~K}$. Regarding the relations between the volumetric heat capacity and water content, it can be concluded that these differences are caused mainly by the magnitude of $\theta$ in the investigated treatments. This agrees with results presented by Johnson and Lowery (1985), which also assessed the higher values of $\mathrm{Cv}$ in no-tillage than in conventional (moldboard) tillage and explained this with reference to the effect of the water content.

Soil thermal diffusivity is also affected by the tillage treatment and as reported by Johnson and Lowery (1985), Anandakumar et al., (2001) it depends on the volumetric water content in the soil. This is in agreement with our results, as soil water content can be amended by tillage, which in turn can influence thermal conductivity, volumetric heat capacity and, consequently, the soil thermal diffusivity. In our study, similar to that of Arshad and Azooz (1996) under unwheeled Mulch (wit higher $\theta)(0-30 \mathrm{~cm}$ depth; Table 2; Figure 3a) D shows lower max. values, and under wheeled plots these values were the same for both treatments (Table 4).

Results from sampled depth of $30-60 \mathrm{~cm}$ and both unwheeled and wheeled plots show lower water content (but still higher than 20\%) in Mulch (Table 2 and 4; Figure 3b and $4 \mathrm{~b}$ ), which, regarding on the phenomenon described above should significant higher D for this treatment. However, for this depth we detected higher thermal diffusivity under Plough. This can mean that despite insignificant differences in bulk density between $\mathrm{M}$ and $\mathrm{P}$ the yearly leading tillage operations in higher soil horizons, their deeper parts became firmed what can meaning more particles connections, what as a one of the factors influenced D, can lead to their increase. 
As was mentioned above, the calculated thermal diffusivity differs between the used methods. If the treatments before and after compaction are compared, values of D calculated with damping depth method are smaller. The problem of comparing estimated results by using various methods is not new and was already discussed by Horton and Wierenga (1983) and Ghuman and Lal (1985). However, calculations from both methods show greater values of $\mathrm{D}$ for samples taken from $30-60 \mathrm{~cm}$ depth. This can indicate that results estimated with both methods are reliable and can be compared. (is understood that damping depth method is a "control" - its use is more common so, the Usowicz approach is validated for a range of soil managements). However, regard on the fact that both methods present advantages and limitations all this factors have to be considered in future investigations in aim to received better results. It is also to be mentioned that for the interpretation of estimated results not only physical properties, but also factors like sampling depth have to be regarded. Anandakumar et al., (2001) showed that the soil layer can be regarded as homogenous since its thickness is only $10 \mathrm{~cm}$. In deeper parts, soil thermal properties, due to differences in the composition of the soil and change in water content, can differ from those at the top layer. For example, Flint and Childs (1986) assessed higher $\lambda$ in deeper soil layers which was related in this case to the greater rock fragment percentage in the subsoil. Kovar et al., (1992) concluded that the influence of tillage practices on root distribution, soil temperature and soil water content reaches at least a depth of $30 \mathrm{~cm}$ (if the ploughing depth is $25 \mathrm{~cm}$ ).

\section{CONCLUSIONS}

The tillage treatments affect the soil thermal regime as follows:

1. Soil thermal properties as heat conductivity and heat capacity are higher and thermal diffusivity lower under conservational tillage treatment what is strongly related with magnitude of soil water content.

2. Soil wheeling (compaction) (with small exceptions at $30-60 \mathrm{~cm} ; \lambda$ in $\mathrm{M}$; $\theta$ in $\mathrm{P}$ ) lead to an increase of the volumetric water content, and as a consequence, their thermal properties and temperature.

3. Thermal diffusivity calculated with two different methods show greater values for deeper soil horizon.

4. Values of thermal diffusivity calculated with two methods differ from each other. This phenomenon, however, is not new and appears if various methods with different boundary conditions are used for calculations of defined properties.

\section{REFERENCES}

Abu-Hamdech, N. A., R. C. Redder. 2000. Soil thermal conductivity: Effects of density, moisture, salt concentration and organic matter. Soil Sci. Soc. Am. J. 64: 1285-1290.

Allmaras, R. R., E. A. Hallauer, W. W. Nelson, and S. D. Evans. 1977. Surface energy balance and soil thermal property modifications by tillage induced soil structure. Minn. Agric. Exp. Stn. Tech. Bull. 306 P.

Anandakumar, K., R. Venkatesan., T. V. Prabha. 2001. Soil thermal properties at Kalkappan in coastal south India. Proc. Indian Acad. Sci. 110 (3): 239-245.

Arshad, M. A., R. H. Azzoz. 1996. Tillage effects on soil thermal properties in a semiarid cold region. Soil Sci. Soc. Am. J. 60: 561-567.

Azzoz, R. H., Arshad, M. A. 1995. Tillage effect on thermal conductivity of two soils in Northern British Columbia. Soil Sci. Soc. Am. J. 59: 1413-1423. 
Bachmann, J. 1997. Thermisches verhalten der Böden. In: Blume, H.P., Felix Henningsen, W. R. Fisher, H.-G. Frede, R. Horn and K.Stahr (Hrsg.): Handbuch der Bodenkunde, 2, Ecomed, Landsberg/Lech, 1-40.

Burrows, W. C., W. E. Larson. 1962. Effect of amount of mulch on soil temperature and early growth of corn. Agron. Journal. 54:19-23.

Chacko, T., P. G. Renuka. 2002. Temperature mapping, thermal diffusivity and subsoil heat flux at Kariavattomof Kerala. Proc. Indian Acad. Sci. (Earth Planet. Sci.), 111(1):79-85.

De Vries, D. A. 1996. Thermal Properties of Soil. In: Van Wijk, W. R. (Hrsg.): Physics of plant Environment. NorthHolland Publishing Company, Amsterdam: 210-235.,3.

Elimoel, A. Elias, R. Cichota, H. H. Torriani., Q. De Jong Van Lier. 2004. Analytical soil- temperature model: Correction for temporal variation of daily amplitude. Soil Sci. Soc. Amer. J. 68:784788.

FAO. 1998. World Reference Base for Soil Resources. World Soil Resources Report 84, Food and Agriculture Organization of the United Nations, Rome.

Flint., A. L., S. W. Childs. 1986. Field procedure for estimating soil thermal environments. Soil Sci. Soc. Amer. J. 51:1326-1331.

Ghuman, B. S.,R. Lal. 1985. Thermal conductivity, thermal diffusivity., thermal capacity of some nigerian soils. Soil Science. 139 (1): 74-80.

Hanks, R. J., D. D. Austin., W.T. Ondrechen. 1971. Soil temperature estimation by a numerical method. Sci. Soc. Am. J. 35: 665-667.
Hanks, R.J. and Ashcroft, G.L. 1980. Applied Soil Physics. Springer ISBN. Berlin, New York.

Hay, R. K. M., J. C. Holmes., E. A. Hunter. 1978. The effect of tillage, direct drilling and nitrogen fertilizer on soil temperature under a barley crop. J. Soil Sci. 29: 174183.

Hillel, D. 1998. Environmental Soil Physics. Academic Press, London, 771 P.

Hopmans, J. W., J. H. Dane. 1986. Thermal conductivity of two porous media as a function of water content, temperature, and density. Soil Science. Vol. 142: 187195.

Horton, R., P. J. Wierenga. 1983. The effect of column wetting on soil thermal conductivity. Soil Sci. 138 (2):102-108.

Johnson, M. D., B. Lowery. 1985. Effect of Three Conservation Tillage Practices on Soil Temperature and Thermal Properties. Soil Sci. Soc. Amer. J. 49:1547-1552.

Kovar, J. L., S. A. Barber., E. J. Kladivko and D. R. Griffith. 1992. Characterization of soil temperature, water content, and maize root distribution in two tillage systems. Soil \& Tillage Research. 24: 11-27.

Licht, M. A., M. Al-Kaisi. 2005. Strip-tillage effect on seedbed soil temperature and other soil physical properties. Soil \& Tillage Research. 80: 233-249.

Maag, M., Finn P. Winther. 1999. Effect of temperature and water on gaseous emissions from soils treated with animal slurry. Soil Sci. Soc. Amer. J. 63: 858865. 
Nidal, H. Abu-Hamdeh., R. C. Reeder. 2000. Soil thermal conductivity-effect of density, moisture, salt concentration, and organic matter. Soil Sci. Soc. Am. J. 64: 1285-1290.

Noborio, K., K. J. Mc Innes. 1993. Thermal conductivity of salt-affected soils. Soil Sci. Soc. Amer. J. 57: 329-334.

Nofziger, D.L., Wu. J. 2002. Soil temperature variations with time and depth. Research Associate, Department of Plant and Soil Science, Oklahoma State University, Stillwater, OK 74078.

Peth, S. 2004. Bodenphysikalische Untersuchungen zur Trittbelastung von Böden bei der Rentierweidewirtschaft an borealen Wald- und subarktischalpinen Tundrenstandorten. Dissertation. Kiel, 160 P. ISSN 64.

Potter, K. N., R. M. Cruse and R. Horton. 1985. Tillage effect on soil thermal properties. Soil Sci. Soc. Amer. J. 49: 968-973.

Radke, J. K. 1982. Managing early season soil temperatures in the northern corn belt using configured soil surfaces and mulches. Soil Sci. Soc. Amer. J. 46: 1067-1071.

Tyson, E. Ochsner, R. Horton., Tusheng Ren. 2001. A new perspective on soil thermal properties. Soil Sci. Soc. Amer. J. 65: 1641-1647.

Usowicz, B.1991. Modelowe badania wplywu wilgotnosci gleby na ksztaltowanie sie temperatury w profilu glebowym. Akademia Rolnicza w Lublinie, Wydzial rolniczy. Praca doktorska. $64 \mathrm{P}$.
Usowicz, B. 1992. Statistical-physical model of thermal conductivity in soil. Polish journal of soil Science. Vol.XXV/1. PL ISSN 0079-2985.

Usowicz, B. 2000. Satystyczno - fizyczne modele przeplywu masy i energii $\mathrm{w}$ osrodku porowatym. Lublin, Acta Agrophysica. ISSN 1234 - 4125.

Usowicz, B. 2002. Szacowanie cieplnych właściwości gleby. Acta Agrophysica, Lublin. 72, 135-165.

Usowicz, B. 2005. Rozkład właściwości cieplnych gleby na czarnym ugorze $\mathrm{i}$ pod murawa. Acta Agrophysica, Lublin. $11 \mathrm{P}$.

Wierenga, P. J., D.R. NielseN., R.M. Hagan .1969. Thermal properties of a soil based upon field and laboratory measurements. Soil. Sci. Soc. A. Proc., Vol. 33.

Wierenga, P. J., D.R. Nielsen., R. Horton and B. Kies. 1982. Tillage effects on soil temperature and thermal conductivity. ASA, SSSA, 677 South Segoe road, Madison, WI53711, U.S.A. Predicting tillage effects on soil Physical Properties and Processes. Special Publishing N44.

Walczak, R., B. Usowicz. 1994. Variability of moisture, temperature and thermal properties in bare soils and in crop field. Int. Agrophysics. 8 (1):161-168.

Zawadzki, S., B. Dobrzański., S. Kowaliński., T. Skawina., F.

Kuźnicki. 1999. Gleboznawstwo. Podrecznik dla studentow. Wydanie IV poprawone i uzupelnione. Panstwowe Wydawnicto Rolnicze i Lesne. Warszawa, 559 P. ISBN 830901703-0. 